\title{
Analisis Ekspresi Kelompok Gen-Gen Pertahanan Pada Tanaman Pisang Dalam Merespons Bakteri Patogen Ralstonia solanacearum
}

\author{
Yunus Effendi ${ }^{1}$, Arief Pambudi ${ }^{2}$, Lulu' Nisrina ${ }^{3}$ \\ ${ }^{1,2,3}$ Program Studi Biologi, Fakultas Sains dan Teknologi, Universitas Al Azhar Indonesia, Jalan \\ Sisingamangaraja, Kompleks Masjid Agung Al Azhar, Kebayoran Baru, Jakarta 12110
}

Penulis untuk Korespondensi/E-mail: effendiy@uai.ac.id

\begin{abstract}
Abstrak - Blood Disease Bacterium (BDB) adalah penyakit pada banyak tanaman bernilai ekonomis seperti tanaman pisang yang disebabkan oleh infeksi soil-borne bakteri patogen Ralstonia solanacearum. Kemampuan R.solanacearum untuk bertahan pada kondisi minimum pada tanah dan luasnya spektrum inang pertumbuhannya termasuk vektor perantara, menyebabkan belum ditemukannya strategi efektif untuk menanggulangi penyebaran penyakit BDB. Pengetahuan tentang respons tanaman pisang terhadap serangan Ralstonia solanacearum, merupakan langkah awal untuk memahami stategi tanaman dalam membentuk sistem pertahanan. Dalam penelitian ini, respons ekspresi molekuler gen-gen terkait pertahanan pada tanaman pisang kepok (Musa paradisiaca) dianalisis menggunakan teknik semikuantitatif real time PCR. Data pada penelitian ini menunjukkan WRKY15 memiliki penurunan ekspresi pada hari ke-3 dan ke-7 pasca infeksi. WRKY18 memiliki ekspresi paling rendah dibandingkan dengan WRKY15 dan WRKY23 serta tidak terdeteksi lagi ekspresinya pada hari ke-5 pasca infeksi karena WRKY18 bersifat represi pada pengaturan sistem pertahanan tanaman basal. Level ekspresi WRKY23 memiliki pola yang konsisten pada hari ke-1 sampai hari ke-7 pasca infeksi karena WRKY23 merupakan salah satu early induced gene. Penelitian ini juga didukung dengan data morfologi yang menunjukkan gejala penyakit layu bakteri berupa penguningan daun pada hari ke-5 pasca infeksi dan pada hari-4 pasca infeksi telah terlihat koloni R.solanacearum pada pseudostem.
\end{abstract}

Kata Kunci - Transkriptomik, WRKY, Ralstonia solanacearum, Penyakit Layu Bakteri

Abstract - Blood Disease Bacterium (BDB) is a disease in many economically valuable plants such as banana plants caused by soil-borne infection of pathogenic bacteria Ralstonia solanacearum. The ability of $R$. solanacearum to withstand minimum conditions on the ground and the extent of its host growth spectrum including intermediate vectors, has resulted in the lack of effective strategies to combat the spread of BDB. Knowledge about banana plant response to Ranstonia solanacearum attack, is the first step to understand crop strategy in forming defense system. In this study, the response of molecular expression of defense-related genes in banana kepok plant (Musa paradisiaca) was analyzed using semi-quantitative real time PCR technique. Data in this study showed WRKY15 had decreased expression on. WRKY18 has the lowest expression compared to WRKY15 and WRKY23 and no longer detected its expression on the 5th postinfection day because WRKY18 is repressive on the regulation of basal plant defense system. The expression level of WRKY 23 has consistent pattern on the 1st day until the 7th postinfection day because WRKY23 is one of the early induced gene. This study was also supported by morphological data showing symptom of bacterial wilt disease in the form of yellowing of leaves on the 5th day post infection and on day 4 post infection has seen colonies $R$. solanacearum on pseudostem. 


\section{PENDAHULUAN}

$\mathrm{B}$ lood Disesase Banana (BDB) atau penyakit layu bakteri adalah penyakit yang menyebabkan kelayuan pada berbagai tanaman ekonomi penting seperti tomat, kentang, jahe, stroberi dan pisang (Alvarez et al. 2010). BDB disebabkan oleh bakteri Ralstonia solanecearum yang pertama kali ditemukan di Sulawesi pada tahun 1921 oleh Gauman dengan nama Pseudomonas celebensis (Hermantoet al. 2013). Saat ini Ralstonia solanecearum disebut sebagai Ralstonia solanecearum species complex (RSCC) karena kompleksitas yang dimilikinya. Diketahui bahwa RSCC memiliki 5 ras yang setiap rasnya memiliki spesifitas inangnya masing-masing. $R$. solanecearum yang menyerang tanaman pisang termasuk ke dalam ras 2 (Alvarez et al. 2010).

BDB yang menyerang tanaman pisang akan menyebabkan kelayuan karena $R$. solanecearum memblok sistem vaskular dari tanaman. Gejala kelayuan pertama kali muncul dengan adanya penguningan daun dari bagian tepi. Gejala kelayuan ini biasanya terdeteksi pada saat tanaman telah dewasa dan akan berbuah sehingga kerugian yang ditimbulkan juga lebih tinggi mengingat biaya produksi yang telah dikeluarkan dan kerugian yang diakibatkan karena gagal panen. Penyakit ini masuk melalui akar tanaman pisang yang mengalami luka lalu berkembang ke sistem vaskular tanaman pisang (NSW Department of Primary Industries 2014).

Sampai saat ini belum ditemukan penanganan yang tepat terhadap BDB yang menyerang tanaman pisang karena ekologi dan epidemologi dari R.solanecearum sangat kompleks dan belum diketahui secara keseluruhan. Sehingga penanganan yang dapat dilakukan pada tanaman pisang dengan BDB adalah mencabut tanaman tersebut apabila telah terdeteksi terserang penyakit. Adapula beberapa penelitian yang mennggunakan bakteri antagonistik seperti Trichoderma harizianum untuk melawan keberadaan R.solanecearum dengan tingkat keberhasilan sebesar $\pm 70 \%$ pada skala laboratorium (Hersanti et al.2009). Besarnya tingkat keberhasilan tersebut tidak menutup kemungkinan $30 \%$ dari $R$. solanecearum tetap melakukan penyebaran untuk memperluas wilayahnya.

Oleh sebab itu diperlukan tindakan preventif sebagai salah satu upaya penanganan dari BDB. Tindakan preventif dapat dilakukan dengan menganalisis transkriptomi gen terkait sitem pertahanan pada tanaman pisang yang terserang BDB. Tindakan ini dirasa cukup efektif untuk menekan penyebaran BDB karena dengan melakukan analisis transkriptomik maka tanaman pisang yang terserang BDB lebih cepat diketahui sebelum munculnya tampak visual seperti kelayuan pada daun pisang.

Salah satu kelompok gen pertahanan yang dapat digunakan adalah kelompok gen WRKY yang berperan penting dalam perkembangan dan responss cekaman pada tanaman (Goel et al. 2016). Gen WRKY diketahui terlibat dalam berbagai responss fisiologis seperti pertahanan terhadap patogen, responss cekaman abiotik, penuaan dan pembentukan trikoma (Li et al. 2014). Beberapa gen WRKY yang telah diketahui merespons patogen adalah WRKY45,WRKY51, WRKY63, WRKY75 (Zhu et al. 2012) dan WRKY23 (Grunewald et al. 2008).

Penelitian ini bertujuan untuk menganalisis respons awal ekspresi kelompok gen WRKY dan penampakan fenotip pada tanaman pisang pasca infeksi R.solanecearum. Data dari penelitian ini diharapkan dapat digunakan sebagai informasi penyusunan database profil molekuler ekspresi early defens related genes tanaman pisang pasca infeksi R.solanecearum. Selain itu, profil responss molekuler tersebut juga diharapkan dapat dimanfaatkan sebagai kandidat marker molekuler tanaman yang terserang R.solanecearum sehingga penyebaran $R$. solanecearum dapat dideteksi lebih awal dan perencanaan penanggulangan R.solanecearum dapat disusun dengan cepat

\section{METODOLOGI}

Waktu dan Tempat Penelitian

Penelitian dilakukan pada bulan November 2016 sampai Juli 2017. Penelitian dilakukan di Green House, Laboratorium Mikrobiologi dan Laboratorium Molekuler Universitas Al Azhar 
Indonesia, Komplek Masjid Agung Al Azhar, Kebayoran Baru, Jakarta Selatan.

\section{Kultur dan Inokulasi $R$. solanecearum Pada Pisang}

Isolat bakteri R.Solanecearum didapat dari Laboratorium Agroteknologi Universitas Andalas, Padang, Sumatera Barat. Bakteri dikultur di media Nutrient Agar (NA) dengan pengenceran $10^{-1}$ sampai $10^{-8}$ dan dihitung koloninya hingga menemukan $10^{8} \mathrm{CFU} / \mathrm{ml}$ yang digunakan untuk infeksi pada tanaman pisang. Bakteri kemudian dikultur di media Nutrint Broth dan diinkubasi selama 24 jam di stirer incubator pada suhu $37^{\circ} \mathrm{C}$ dengan kecepatan $120 \mathrm{rpm}$. Bakteri yang telah diinkubasi kemudian diencerkan dengan NB hingga pengenceran yang menentukan jumlah bakteri sebanyak $10^{8} \mathrm{CFU} / \mathrm{ml}$. Hasil pengenceran tersebut digunakan untuk infeksi pada tanaman pisang dengan dosis $2,5 \mathrm{ml}$ yang berisi $10^{8} \mathrm{CFU} / \mathrm{ml}$ (Ramirez et al. 2015).

Pada penelitian ini digunakan 30 tanaman pisang yang akan dibagi menjadi dua kelompok yaitu kelompok perlakuan sebanyak 24 tanaman dan kelompok kontrol sebanyak 6 tanaman. Kelompok perlakuan akan dibagi menjadi 8 kelompok yaitu kelompok $\mathrm{H} 1, \mathrm{H} 2$, $\mathrm{H} 3, \mathrm{H} 4, \mathrm{H} 5, \mathrm{H} 6, \mathrm{H} 7$ pasca inokulasi dan kelompok tanaman pisang untuk pengamatan fenotip. Kelompok kontrol akan dibagi menjadi 2 kelompok yaitu kelompok tanaman pisang yang akan diambil daunnya untuk isolasi RNA dan kelompok tanaman yang akan diamati penampakan fenotipnya.

\section{Pengamatan Fenotip Tanaman Pisang}

Pengamatan fenotip tanaman pisang dilakukan pasca inokulasi $R$. solanecearum yang dilakukan setiap hari selama satu bulan untuk mendokumentasikan perkembangan gejala penyakit layu bakteri dan dilanjutkan setiap satu minggu sekali hingga tanaman pisang menunjukkan gejala kematiannya.

\section{Isolasi RNA}

RNA total diisolasi dari bagian daun menggunakan GENEzol ${ }^{\mathrm{TM}}$ Reagent dan dimurnikan dengan phenol:chloroform:isoamil alkohol 1 phase (PCI) untuk setiap sampel yaitu H1, H2, H3, H4, H5, H6, H7 dan kontrol. Sebanyak 50-100 mg sampel dihaluskan dengan nitrogen cair lalu dipindahkan ke tabung 1,5 ml steril dan ditambahkan $1 \mathrm{ml}$ GENEzolTM Reagent kemudian disentrifugasi dengan kecepatan 5000 rpm selama 10 menit. Supernatan yang didapat ditambahkan 0,5-1 ml PCI dan disentrifugasi pada $13.000 \mathrm{~g}$ selama 5 menit. Pemurnian menggunakan PCI dilakukan sebanyak 2-3 kali sampai warna supernatan yang didapat tidak keruh. Sampel yang telah dimurnikan dengan PCI kemudian ditambah $200 \mu \mathrm{l}$ kloroform dan divorteks kurang lebih selama 10 detik lalu disentrifugasi dengan kecepatan $12.000 \mathrm{~g}$ selama 10 menit. Supernatan yang didapat dipresipitasi dengan menambahkan 1 volume isopropanol dingin dan diinkubasi selama 10 menit pada suhu ruang lalu disentrifugasi pada $12.000 \mathrm{~g}$ selama 5 menit dan membuang fase supernatannya. Pellet yang didapat merupakan RNA total hasil isolasi dicuci dengan $1 \mathrm{ml}$ alkohol $70 \%$ dan disentrifugasi selama 5 menit pada kecepatan 1 $2.000 \mathrm{~g}$ kemudian dikeringkan pada suhu ruang selama 5-10 menit lalu diresuspensi menggunakan $50 \mu \mathrm{lddH} 2 \mathrm{O}$.

\section{Sintesis cDNA dan Amplifikasi PCR}

RNA total yang telah diresuspensi dengan 50 $\mu \mathrm{l}$ ddH2O dikuantifikasi menggunakan BioDrop Duo UVI/VIS Spectrophotometer. RNA yang telah terkuantifikasi kemudian diambil sebanyak $1 \mu \mathrm{g}$ untuk sintesis cDNA menggunakan BioLine Tetro cDNA Synthesis Kit.

Amplifikasi dilakukan dengan menggunakan 1 $\mu \mathrm{l}$ cDNA, $1 \mu \mathrm{l}$ primer, $10,5 \mu \mathrm{l}$ ddH2O dan 12,5 $\mu 1$ Redmix PCR Kit dari BioLine sebanyak 36 siklus dengan kondisi denaturasi $99{ }^{\circ} \mathrm{C}$ selama 2 menit, annealing dengan optimasi selama 15 detik, elongasi $72{ }^{\circ} \mathrm{C}$ selama 15 detik dan pasca elongasi $72{ }^{\circ} \mathrm{C}$ selama 10 menit. Hasil amplifikasi kemudian divisualisasi dengan elektroforesis menggunakan $25 \mathrm{ml} \mathrm{1 \%}$ agarose yang dicampur $1 \mu \mathrm{l}$ redsafe gel staining kemudian dijalankan pada $1 \mathrm{x}$ bufffer TAE $75 \mathrm{~V}$ selama 45 menit (IPDN 2014). 
Tabel 1. Sekuens Primer

\begin{tabular}{|lcc|}
\hline \multicolumn{1}{|c}{ Gen } & Forward & \multicolumn{1}{c|}{ Reverse } \\
ACTIN & GCCAGTGGTCGTACAACCG & TCATGACGTAATCAGTAAGGTCAC \\
\hline WRKY15 & CGACCGAGATTGATCCAAC & CACTTCCATGCTGCTTCCTG \\
\hline WRKY18 & \\
\hline
\end{tabular}

\section{HASIL DAN PEMBAHASAN}

Pengamatan yang dilakukan pada tanaman pisang menunjukkan perubahan pada hari ke-5 pasca infeksi R.Solanacearum. Gejala yang muncul pertama kali pada tanaman pisang adalah perubahan warna daun menjadi kuning yang muncul dari bagian tepi daun. Hal serupa juga terjadi pada penelitian yang dilakukan oleh Hadiwiyono et al. (2011) bahwa gejala penyakit layu bakteri pertama kali ditunjukkan dengan perubahan warna tepi daun menjadi kuning. Perubahan warna daun semakin jelas seiring dengan bertambahnya waktu pasca infeksi bakteri seperti yang ditunjukkan pada Gambar 1. Hal itu dikarenakan R.solanacearum yang diinfeksikan ke tanaman pisang telah membentuk koloni dan menyebabkan terhentinya sistem vaskular sehingga terjadi kelayuan pada tanaman pisang (Subedi 2015). Meskipun demikian, gejala kerusakan pada tanaman pisang yang diinfeksi oleh R.solanacearum relatif lebih lambat jika dibandingkan dengan gejala kerusakan yang diakibatkan oleh cendawan patogen Fusarium oxysporum f.sp. cubense penyebab penyakit layu panama. Lambatnya laju gejala penyakit layu bakteri dapat disebabkan oleh motilitas dari bakteri yang semakin berkurang apabila berada di dalam tanaman. Hal itu disebabkan perilaku R.solanacearum menjadi berbeda apabila sudah berada di dalam jaringan pembuluh tanaman yang seharusnya dapat bergerak bebas pada $10^{8} \mathrm{CFU} / \mathrm{ml}$ (Julie et al. 2001).

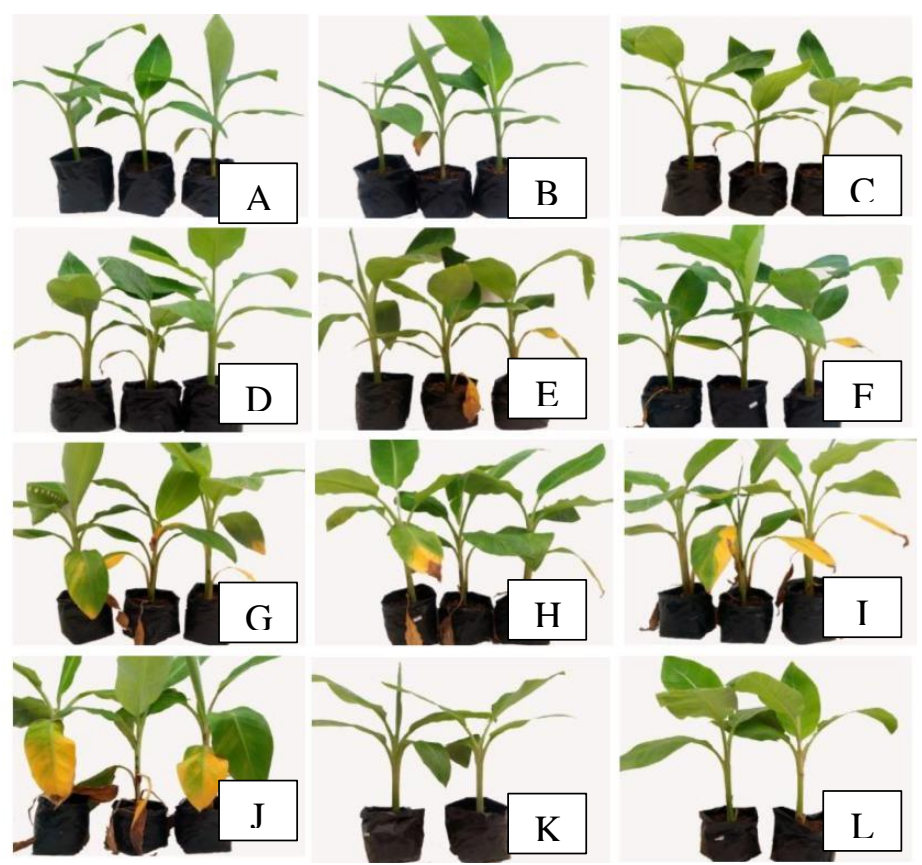

Gambar 1. Gejala penyakit layu bakteri pada tanaman pisang pasca infeksi (A) hari ke-5 pasca infeksi (B) hari ke-10 pasca infeksi (C) hari ke-15 pasca infeksi (D) hari ke-20 pasca infeksi (E) hari ke-25 pasca infeksi

(F) hari ke-30 pasca infeksi (G) 5 minggu pasca infeksi (H) 6 minggu pasca infeksi (I) 7 minggu pasca infeksi (J) 8 minggu pasca infeksi (K) kontrol pada hari ke-30 (L) kontrol pada minggu ke-8. 
Selain terjadi penguningan pada daun, gejala penyakit layu bakteri juga ditunjukkan dengan adanya perubahan warna pada jaringan pembuluh yang disertai dengan adanya lendir dan keberadaan ooze dari R.solanacearum (Teng et al. 2014). Data sayatan membujur pada pseudostem tanaman pisang menunjukkan bahwa pada hari ke-4 pasca infeksi R.solanacearum telah menunjukkan perubahan warna disekitar daerah infeksi menjadi warna coklat (Gambar 2).
A

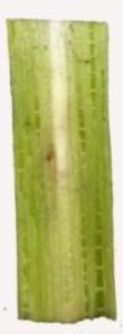

D

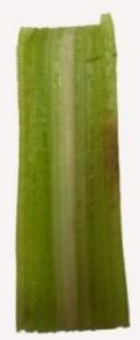

G

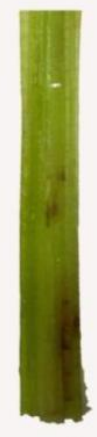

B

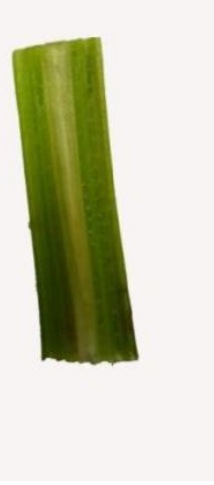

E

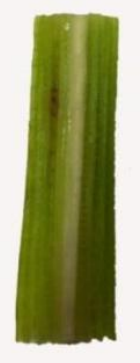

$\mathrm{H}$
C

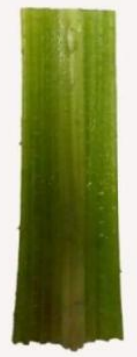

F
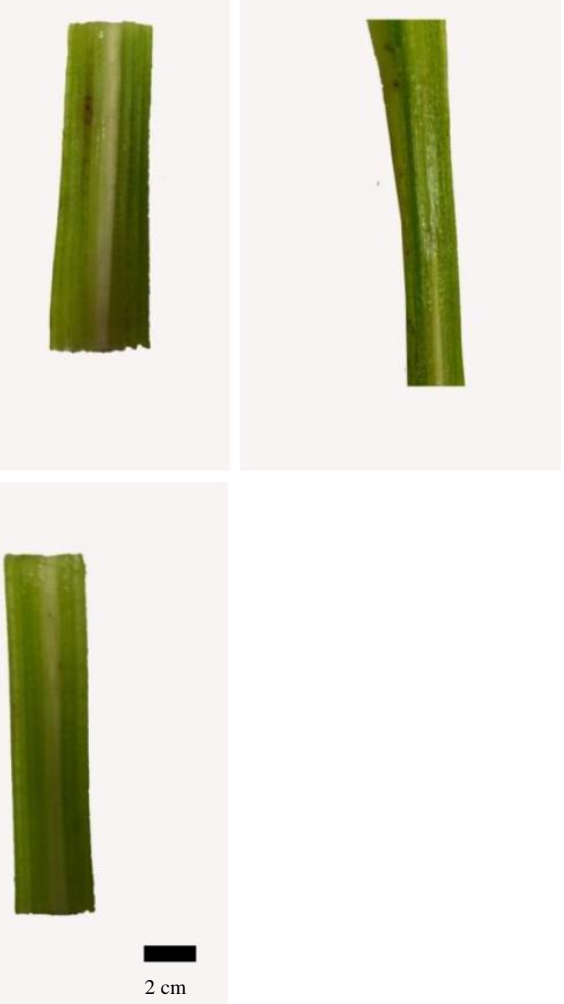

Gambar 2 Sayatan membujur psedostem pasca infeksi R.Solanacearum (A) hari ke-1 pasca infeksi (B) hari ke-2 pasca infeksi (C) hari ke-3 pasca infeksi (D) hari ke-4 pasca infeksi (E) hari ke-5 pasca infeksi (F) hari ke-6 pasca infeksi (G) hari ke-7 pasca infeksi (G) kontrol negatif.

Gen WRKY pada Musa acuminata dan Musa balbisiana telah dilaporkan oleh Goel et al. (2016) memiliki 147 dan 132 anggota gen yang dibagi menjadi tiga kelompok yaitu kelompok I, II dan III. Pengelompokkan tersebut dilakukan berdasarkan keberadaan zinc finger
(ZnF) pada gen WRKY. ZnF adalah motif struktural dari protein-protein kecil yang ditandai dengan adanya koordinasi dari satu atau lebih dari ion $\mathrm{Zn}$ yang stabil (McDowall 2007). 
WRKY15 termasuk kedalam kelompok IId (Eulgem et al. 2000). Kelompok tersebut dapat terekspresi apabila terinduksi oleh cekaman biotik seperti serangan patogen dan cekaman abiotik seperti salinitas, tekanan osmotis, stres oksidatif, temperatur dan ketersediaan $\mathrm{CO} 2$ yang rendah (Vandirauwera et al. 2012). Penelitian ini menunjukkan WRKY15 mengalami penurunan ekspresi pada hari ke-3 dan ke-7 pasca infeksi R.solanacearum. Hal itu dapat disebabkan karena sifat WRKY15 yang mampu merespon dua jenis stres yaitu biotik dan abiotik. Diduga karena sifat tersebut, ekspresi WRKY15 lebih jelas dibandingkan dengan ekspresi gen yang lainnya. Adanya penurunan ekspresi WRKY15 pada hari ke-3 dan ke-7 dapat terjadi dikarenakan tidak ada kombinasi cekaman pada tanaman pisang. Dilaporkan oleh Choudhury et al. (2017) bahwa kombinasi cekaman mampu menimbulkan ekspresi transkirptomik yang unik yaitu tidak diubahkan ratusan transkrip apabila hanya melibatkan satu cekaman saja.

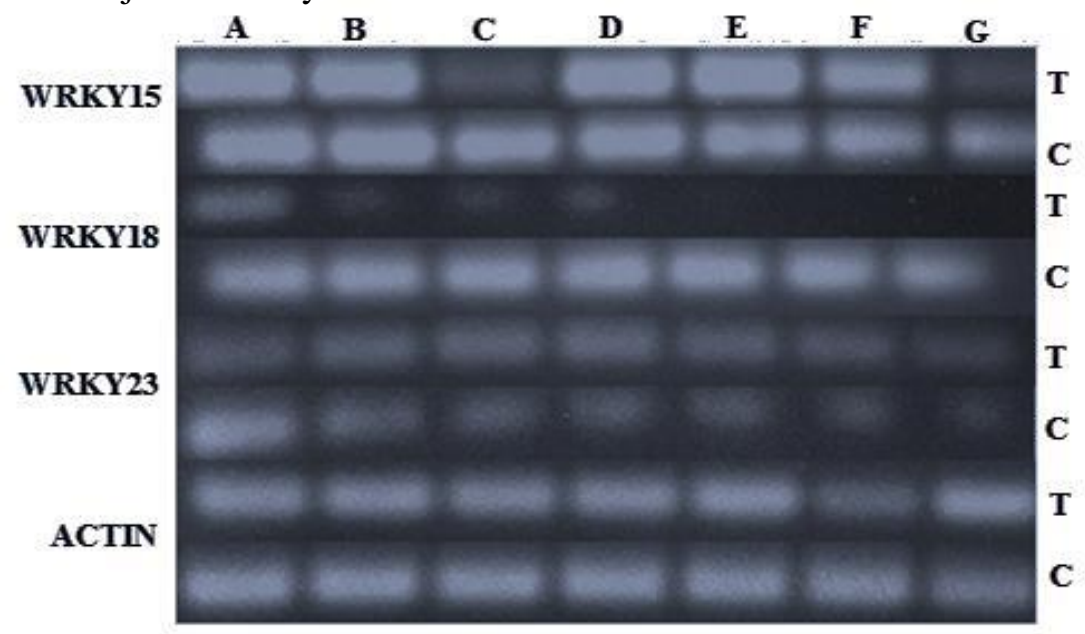

Gambar 3 Ekspresi semi kuantitatif WRKY15, WRKY18, WRKY23 dan ACTIN pada pisang pasca infeksi R.solanacearum. (T) treatment (C) kontrol (A) hari ke-1 pasca infeksi (B) hari ke-2 pasca infeksi (C) hari ke-3 pasca infeksi (D) hari ke-4 pasca infeksi (E) hari ke-5 pasca infeksi (F) hari ke-6 pasca infeksi (G) hari ke-7 pasca infeksi.

WRKY18 termasuk ke dalam kelompok IIa. Kelompok ini mampu menanggapi cekaman biotik di jalur asam salisilat dalam pertahanan tanaman (Karim et al. 2015). Asam salisilat memiliki peranan penting dalam respons cekaman tanaman karena asam salisilat dapat memediasi respons pertahanan tanaman terhadap patogen. Selain itu, asam salisilat juga merespons cekaman abiotik seperti kekeringan, dingin, keracunan loggam berat, panas dan cekaman osmotik (Vincente \& Plasencia 2011). Pada penelitian ini menunjukkan bahwa ekspresi WRKY18 jauh lebih rendah dibandingkan ekspresi gen yang lainnya karena WRKY18 bersifat represi yang mengendalikan pertahanan basal (Pandey et al. 2010).

WRKY23 termasuk termasuk ke dalam kelompok IIc yang mengatur regulasi etilen dan penuaan sel terkait asitelina (Goel et al. 2016). Etilen adalah salah satu hormon yang terdapat di tumbuhan yang bekerja di saat tumbuhan mengalami kondisi kritis seperti merespons cekaman biotik maupun abiotik (Wang et al. 2004). Selain itu, WRKY kelompok II juga dilaporkan mampu menganggapi respons terhadap infeksi patogen seperti jamur ataupun nematoda. Grunewald et al. (2008) melaporkan bahwa WRKY23 berperan pada responss pertahanan Arabidopsis yang diinfeksi oleh nematoda dan mempengaruhi aktivitas auksin di dalamnya sebagai resistensi terhadap infeksi nematoda.

Konsistennya ekspresi WRKY23 pada hari ke1 sampai hari ke-7 pasca infeksi R.solanacearum dikarenakan WRKY23 adalah early-induced gene yaitu gen yang pertama kali diinduksi setelah terjadi cekaman pada tanaman, salah satunya adalah pelukaan yang disebabkan oleh bakteri (Levee et al. 2009). WRKY23 yang terkespresi setelah terjadi cekaman pada tanaman akan memodulasi sintesis hormon etilen yang mampu merespons cekaman biotik dan abiotik (Wnag et al. 2004) serta hormon auksin yang terakumulasi setelah 
terjadi peningkatan level ekspresi WRKY23 (Grunewald et al. 2008).

\section{KESIMPULAN}

Infeksi R.solanacearum pada tanaman pisang mampu mengubah level ekspresi WRKY15, WRKY18 dan WRKY23. WRKY15 memiliki ekspresi yang fluktuatif dikarenakan WRKY15 mampu merespon cekaman biotik dan abiotik.

WRKY18 memiliki level ekspresi yang paling rendah dikarenakan WRKY18 bersifat represi pada sistem pertahanan tanaman basal. Adapun WRKY23 memiliki level ekspresi yang stabil dikarenakan WRKY23 merupakan early induced gene yang aktif terhadapt cekaman biotik seperti infeksi bakteri.

\section{SARAN}

Perlu dilakukan penelitian transkriptomik lanjutan terhadap level ekspresi gen terkait pertahanan yang melibatkan cekaman abiotik terhadap gen-gen yang telah dilakukan penelitian agar dapat dipastikan bahwa gen tersebut betul-betul terekspresi oleh cekaman biotik ataupun abiotik.

\section{UCAPAN TERIMAKASIH}

\begin{tabular}{lrrr} 
UCAPAN & TERIMAKASIH & KAMI \\
SAMPAIKAN & \multicolumn{2}{c}{ KEPADA } & LP2M \\
UNIVERSITAS & AL & AZHAR & INDONESIA \\
YANG & TELAH & MEMBERIKAN \\
DUKUNGAN & DANA & PADA & PENELITIAN \\
INI. & & &
\end{tabular}

\section{DAFTAR PUSTAKA}

[1] Alvarez B, Biosca EG, Lopez MM. 2010. On the life of Ralstonia solanacearum, a destructive bacterial plant pathogen. Technology and Education Topics in Applied and Microbial Biotechnology. Hal 267-279.

[2] Choundhury FK, Rivero RM, Blumwald E, Mittler R. 2017. Reactive oxygen species, abiotic stress and stress combination. The Plant Journal. 90: 856-867.
[3] Eulgem T, Rushton PJ, Robatzek S, Somssich IE. 2000. The WRKY superfamily of plant transcrition factors. Reviews. Trends in Plant Science. 5 (5): 199-205.

[4] Hadiwiyono. 2011. Blood bacterial wilt disease of banana: the distributin of pathogen in infected plant, symptoms, and potentiality of diseases tissues as sourceod infective inoculums. Nusantara BIOSIENCE. Vol 3 (3): 112-117.

[5] Hermanto C, Eliza, Emilda D. 2013. Bunch managenet of banana to control blood disease. Australian Plant Pathol. Vol 42: 653-658.

[6] Hersanti, R. T., A. Rupendi, Purnama, Hanudin, B. Marwoto and O. S. Gunawan. 2009. Filtration of some isolates Pseudomonas fluorescens, Bacillussubtilis and Trichoderma harzianum Antagonistic to $\mathrm{R}$. solanacearum inpotatoes. ( in Indonesia) J.Agrikultura 20(3): 198-203

[7] [NSW] Department of Primary Industries. 2014. Exotic Pest Alert. Department of Agriculture Queensland.

[8] Goel R, Pandey A, Trivedi PK, Asif H. 2016. Genome-wide analysis of the Musa $W R K Y$ gene family: evolution and differential expression during development and cekamans. Frontiers in Plant Science. Vol 7: 1-13.

[9] Grunewald W, Karimi M, Wieczorek K, Capelle EVD, Wischnitzki E, Grundel F, Inzé D, Beeckam T, Gheysen G. 2008. A role for AtWRKY23 in feeding site establishment of plant-parasitic nematodes. Plant Physiology. Vol 148: 358-365.

[10] [IPDN]. The International Plant Diagnostic Network. 2014.

Bacterial Wilt Disease Ralstonia solanacearum.

[11] Julie TK, Huang H, Allen C. 2001. Ralstonia solanacearum nedds motility for invasive virulence on tomato. Journal of Bacteriology. 182 (12): 3597- 3602.

[12] Karim A, Jiang Y, Guo L, Ling Z, Ye S, Duan Y, Li C, Luo K. 2015. Isolation and characterization of a subgroup IIa WRKY transcription factor PtrWRKY40 from Populus trichocarpa. Tree Physiology.

[13] Li J. 2014. Role ofWRKY Transcription Factors in Arabidopsis Development and 
Cekamans Responssses. [Disertasi]. Univesity of Helsinki. Finland.

[14] Levee V, Major I, Levasseur C, Tremblay L, MacKay J, Séguin. 2009. Expression profiling and functional analysis of Populus WRKY23 reveals a regulatory role in defense. New Phytologist. Vol 184: 48-70.

[15] McDowall J. 2007. Molecule of the Month: Zinc Fingers. https://www.ebi.ac.uk/interpro/potm/200 7_3/Pagel.htm. (Diakses pada 12 Juli 2016)

[16] Pandey SP, Roccaro M, Schon M, Logemann E, Somssich IE. 2010. Transcritional reprogramming regulates by WRKY18 and WRKY40 facilities powdery mildew infection of Arabidopsis. The Plant Journal. 64: 912923.

[17] Ramirez JG, Munoz M, Patino LF, Morales JG. 2015. Banana moko disease management with resistance inducers and chlorine dioxide. Agronomia Columbia. 33 (2): 194-20

[18] Subedi N. 2015. Characterization and Management of Ralstonia solanacearum Population in South Asia. [Disertasi]. The Ohio State University.
[19] Teng SK, Aziz NAA, Mustafa M, Laboh R, Ismail IS, Sulaiman SR, Azizan AA, Devi S. 2014. The occurance of blood disease of banana in Selangor, Malaysia. International Journal of Agriculture \& Biology. 18(1): 92-97.

[20] Vanderauwra S, Vandenbroucke K, Inze A, Cotte B, Muhlenbock P, Rycke RD, Naouar N, Gaever TV, Montagu MCEV, Breusegem FV. 2012. AtWRKY15 perturbation abolishes the mitochondrial stress responsse that steers osmotic stress tolerance in Arabidopsis. PNAS. 109 (49): 20113-20118.

[21] Vicente MRS, Plasencia J. 2011. Salicylic acid beyond defence: its role in plant grpwth and development. Journal of Experiment Botany. Vol 62 (10): 3321-3338.

[22] Wang KLC, Yoshida H, Lurin C, Ecker JR. 2004. Regulation of ethylene gas biosynthesis by the Arabidopsis ET01 protein. Nature. Vol 34: 945-950.

[23] Zhu QH, Stephen S, Kazan K, Jin G, et al. 2012. Characterization of the defense trasncriptome responssive to Fusarium oxysporum-infection in Arabidopsis using RNA-seq. Elsevier. 1-14. 